\title{
MERCURY IN TUNAS AND BLUE MARLIN IN THE NORTH PACIFIC OCEAN
}

\author{
Paul E. DrevnicK ${ }^{\mathrm{a}, \mathrm{b}, *}$ and Barbara A. Brooks ${ }^{\mathrm{c}}$ \\ ${ }^{a}$ University of Michigan Biological Station and School of Natural Resources and Environment, Ann Arbor, Michigan, USA \\ ${ }^{\mathrm{b}}$ Environmental Monitoring and Science Division, Alberta Environment and Parks, Calgary, Alberta, Canada \\ ${ }^{c}$ Hazard Evaluation and Emergency Response Office, Hawaii Department of Health, Honolulu, Hawaii, USA
}

(Submitted 5 December 2016; Returned for Revision 16 January 2017; Accepted 3 February 2017)

\begin{abstract}
Models and data from the North Pacific Ocean indicate that mercury concentrations in water and biota are increasing in response to (global or hemispheric) anthropogenic mercury releases. In the present study, we provide an updated record of mercury in yellowfin tuna (Thunnus albacares) caught near Hawaii that confirms an earlier conclusion that mercury concentrations in these fish are increasing at a rate similar to that observed in waters shallower than $1000 \mathrm{~m}$. We also compiled and reanalyzed data from bigeye tuna (Thunnus obesus) and blue marlin (Makaira nigricans) caught near Hawaii in the 1970s and 2000s. Increases in mercury concentrations in bigeye tuna are consistent with the trend found in yellowfin tuna, in both timing and magnitude. The data available for blue marlin do not allow for a fair comparison among years, because mercury concentrations differ between sexes for this species, and sex was identified (or reported) in only 3 of 7 studies. Also, mercury concentrations in blue marlin may be insensitive to modest changes in mercury exposure, because this species appears to have the ability to detoxify mercury. The North Pacific Ocean is a region of both relatively high rates of atmospheric mercury deposition and capture fisheries production. Other data sets that allow temporal comparisons in mercury concentrations, such as pacific cod (Gadus macrocephalus) in Alaskan waters and albacore tuna (Thunnus alalunga) off the US Pacific coast, should be explored further, to aid in understanding human health and ecological risks and to develop additional baseline knowledge for assessing changes in a region expected to respond strongly to reductions in anthropogenic mercury emissions. Environ Toxicol Chem 2017;36:1365-1374. (C) 2017 SETAC
\end{abstract}

Keywords: Mercury Methylmercury Bioaccumulation Fish Ocean

\section{INTRODUCTION}

As a result of anthropogenic inputs, the mercury content of the global ocean has increased, on average, by 2.6 times in waters from depths of $0 \mathrm{~m}$ to $1000 \mathrm{~m}$ and by 1.1 times for all depths, compared with a preanthropogenic inventory [1]. Anthropogenic influence is most pronounced in the northern hemisphere, where anthropogenic emissions of mercury to the atmosphere are greatest [2]. Mercury concentrations in North Pacific intermediate waters increased at a rate of $3 \% / \mathrm{yr}$ between 1995 and 2006 and are projected to double from 1995 to 2050 if current mercury deposition rates are maintained [3]. In North Atlantic waters, mercury concentrations peaked in the $1980 \mathrm{~s}$ or $1990 \mathrm{~s}$ and are now declining, at a rate of $4.3 \% / \mathrm{yr}$ between 1999 and 2010, in response to environmental regulations that controlled mercury releases to water [4] and air [5]. The Arctic Ocean, which is relatively less studied, is the ocean basin where anthropogenic sources (largely outside of the basin) currently contribute the most (among all basins) to the total deposition of mercury [2], although climateinduced increases in riverine fluxes of mercury [6] are also important in driving modeled increases in mercury concentrations in seawater [7].

In the open ocean, mercury from atmospheric deposition can be transformed in the surface mixed layer and the pycnocline to methylmercury, which bioaccumulates in food webs. Measurements of methylmercury in ocean water columns $[3,8]$ suggested

This article includes online-only Supplemental Data.

* Address correspondence to drevnick@umich.edu or paul.drevnick@gov.ab.ca

Published online 6 March 2017 in Wiley Online Library

(wileyonlinelibrary.com).

DOI: $10.1002 /$ etc.3757 that mercury is methylated in situ, because concentrations of methylmercury peaked in the pycnocline, where sinking particles of organic matter are decomposed by microbes. Incubation experiments, in which methylmercury formed from seawater amended with isotopically labeled inorganic mercury, provided unequivocal evidence that in situ methylation can occur $[9,10]$. Furthermore, Blum et al. [11] used natural abundance mercury isotopes in fish collected from discrete depths in the North Pacific to determine, by mass balance, that $20 \%$ to $40 \%$ of methylmercury is formed in the surface mixed layer $(<50 \mathrm{~m})$ and $60 \%$ to $80 \%$ is formed in the pycnocline $(50-600 \mathrm{~m})$. These estimates were possible because photochemical reactions cause massindependent fractionation of odd mercury isotopes [12], and the mass-independent fractionation signature of methylmercury (observed in $\Delta^{199} \mathrm{Hg}$ and $\Delta^{201} \mathrm{Hg}$ values) decreased with the depth at which fish fed. In the surface mixed layer, photodemethylation leaves a residual pool of methylmercury high in $\Delta^{199} \mathrm{Hg}$ and $\Delta^{201} \mathrm{Hg}$ values, available for bioaccumulation. Decreases in $\Delta^{199} \mathrm{Hg}$ and $\Delta^{201} \mathrm{Hg}$ values with depth are the result of the dilution of methylmercury produced in the surface mixed layer (and exported to waters below) by methylmercury produced at depths where photodemethylation does not occur. Finally, the carbon stable isotope composition of methylmercury in tuna collected from the Adriatic Sea $\left(\delta^{13} \mathrm{C}=-22.1 \pm 1.5 \%\right.$ ) closely matches that of algal-derived particulate organic matter $\left(\delta^{13} \mathrm{C}=-21 \%\right.$ o $)[13]$.

Mercury concentrations in biota respond to changes in inputs of mercury to the ocean. In the North Atlantic, which has declining mercury concentrations in water in response to environmental regulations in North America and Europe, Cross et al. [14] and Lee et al. [15] documented declines in mercury concentrations of bluefish (Pomatomus saltatrix) and Atlantic bluefin tuna (Thunnus thynnus), respectively, 
captured from the Northwest Atlantic coast. Over the past $6000 \mathrm{yr}$, mercury concentrations in bones of Pacific cod (Gadus macrocephalus; recovered from a small island in the Gulf of Alaska) have fluctuated in sync with climate changes [16], with the highest concentrations occurring when glacial melting and sea-level rise caused coastal flooding that is speculated to have increased the flux of mercury and methylmercury from land to water. In the modern record for the North Pacific, where mercury concentrations in water are increasing [3] as a result of export of atmospheric mercury from Asia [17], increasing trends of mercury concentrations have also been observed in yellowfin tuna (Thunnus albacares) [18] and in black-footed albatross (Phoebastria nigripes) [19]. In the Arctic Ocean, mercury concentrations in marine mammals and birds have been increasing since approximately 1900 [20-24], and Dietz et al. [22] estimated that anthropogenic sources now contribute $>90 \%$ of mercury accumulated in arctic biota.

Humanity's history with mercury has largely been of (mis) use for short-term economic gains that pollute the local and global environment, but recent and current management and policy efforts have resulted, and will continue to result, in declining mercury concentrations in fish-the main vector through which humans are exposed to mercury-and other environmental media. Ocean fish from offshore and high seas fisheries are a major source of food for humans, but are ubiquitously contaminated with mercury. Given that there are no significant anthropogenic releases of mercury in the open ocean, it is apparent that mercury is a global pollutant, and an international convention is required to control emissions to the atmosphere. The Minamata Convention [25] mandates the elimination or reduction of mercury uses and releases, as well as requiring the monitoring of mercury in environmental media, including fish, to evaluate effectiveness. To assess changes in mercury concentrations in fish, it would be advantageous to choose species of societal and/or ecological importance, with historical data against which changes can be assessed, and from areas expected to respond strongly to declining mercury emissions.

In the present study we examine data from 3 species of fishyellowfin tuna, bigeye tuna (Thunnus obesus), and blue marlin (Makaira nigricans) — sampled during the past 4 decades from the North Pacific near Hawaii. Tunas, generally, constitute globally important commercial fisheries, with a total catch of 5 million metric tons in 2014 [26] worth an estimated USD \$42.21 billion [27]. In the United States, consumption of tunas is the single biggest vector of mercury exposure for humans, accounting for $39 \%$ of mercury uptake from all sources [28]. Blue marlin, apex marine predators that have mercury concentrations among the highest of all fish species [29], are caught primarily as by-catch by the tuna industry and comprise comparatively small commercial fisheries; for example, from 2005 to 2011, the commercial harvest of blue marlin in Pacific waters averaged 17.7 metric tons/yr [30]. The North Pacific is an ocean region expected to respond "most strongly" to changes in anthropogenic mercury emissions [2]. We report that sizeadjusted mercury concentrations in yellowfin tuna and bigeye tuna appear to be increasing in step with loadings, and thus future monitoring efforts should include these species from this location (Hawaii). Blue marlin, because of historical data sets that are incomplete and an apparent ability to demethylate methylmercury and sequester inorganic mercury, would be a poor choice for evaluating the effectiveness of the Minamata Convention.

\section{METHODS}

For yellowfin tuna and bigeye tuna, data sources were Rivers et al. [31] (yellowfin tuna only), Thieleke [32], Kraepiel et al. [33] (yellowfin tuna only), Brooks [34], Kaneko and Ralston [35], and Choy et al. [36]. Each of these sources reported data for individual fish for year of collection, approximate location (all Hawaii), size (mass in $\mathrm{kg}$ ), and (total) mercury concentration in white muscle (ppm in wet tissue). Tissue samples of white muscle were not taken consistently from the same carcass location across studies. Bosch et al. [37], however, reported that no differences were found among 4 white muscle portions across the carcass (of 14 yellowfin tuna) for each of total mercury, methylmercury, and inorganic mercury. Data were gathered directly from tables [31-33], by digitizing scatterplots from figures [36], or from contributions by the original authors [34,35]. Data from Rivers et al. [31], Thieleke [32], Kraepiel et al. [33], and Choy et al. [36] were used in a recent compilation and reanalysis of mercury concentrations of yellowfin tuna [18] that summarized the quality assurance/quality control procedures of these studies that ensured validity of data. Data from Brooks [34] and Kaneko and Ralston [35] (i.e., not in that compilation) are also of high quality. The only data set used in the present study that was not previously published in the peer-reviewed literature is that of Brooks [34]: samples were digested and analyzed for total mercury using US Environmental Protection Agency (EPA) method 7471, and digestion batches included a (noncertified) reference material (mean recovery of $97.5 \%$ of known value), duplicates (mean relative standard deviation of $9.46 \%$ ), and spikes (mean recovery of $85.3 \%$ ). Furthermore, Brooks [34] had a subset of samples analyzed by a separate, independent laboratory, and the mean relative standard deviation for duplicates between laboratories was $5.97 \%$. Kaneko and Ralston [35] used a custom method for digestion of fish tissues for analyses of mercury and selenium, digestion batches included certified reference materials, duplicates, and spikes, and total mercury was analyzed by cold-vapor atomic absorption spectrophotometry.

Mercury concentrations in tunas (within and not between species) were compared among years (1971, 1998, 2002, 2006, and 2008) by analysis of covariance (ANCOVA), with size as the covariate. For yellowfin tuna, Drevnick et al. [18] used a size range of $22 \mathrm{~kg}$ to $76 \mathrm{~kg}$ in the ANCOVA to compare mercury concentrations among the data sets from 1971 [31,32], 1998 [33], and 2008 [36], because that size range $( \pm 5 \mathrm{~kg})$ was common to all 3 data sets. Furthermore, removing fish less than $22 \mathrm{~kg}$ was necessary, because data from those fish did not adhere to the assumption of linearity. For the present reanalysis, which updates the record for yellowfin tuna with data from 2002 [34] and 2006 [35], we used the same size range, which excluded 2 fish from 2002 (both less than $22 \mathrm{~kg}$ ) and 8 fish from 2006 ( 6 less than $22 \mathrm{~kg}, 2$ greater than $76 \mathrm{~kg}$ ). Note that for the analysis by Drevnick et al. [18], one time period (2008) with low sample size $(n=14)$ showed an increase in mercury concentrations over the earlier time periods $(1971,1998)$. The data from 2002 and 2006 provide for more confidence in the present reanalysis and better time resolution during the transition to higher mercury concentrations. For bigeye tuna, fish from $16 \mathrm{~kg}$ to $76 \mathrm{~kg}$ were used for the ANCOVA, because that size range $( \pm 5 \mathrm{~kg})$ was common to all $4 \mathrm{yr}$ with data sets: 1971 [32], 2002 [34], 2006 [35], and 2008 [36]. (As a note, in each of these data sets for bigeye tuna, mercury concentration is linear with size for the full range of sizes, including small individuals.) Outliers were identified with Tukey box plots, confirmed by one-sided Grubbs' tests, and removed from the data sets. The 
ANCOVAs used type III sums of squares. Tukey's honest significant difference (HSD) tests were used (post hoc) to determine differences between years.

For blue marlin, data sources were Rivers et al. [31], Thieleke [32], Schultz et al. [38], Schultz and Crear [39], Unninayar and Ito [40], Brooks [34], and Kaneko and Ralston [35]. Each of these sources reported data for individual fish for year of collection, approximate location (all Hawaii), size (mass in $\mathrm{kg}$ ), and (total) mercury concentration in muscle (ppm in wet tissue). In 3 of the 7 studies [32,39,40], sex was identified (or reported), which is important because, unlike tunas [41,42], blue marlin exhibit sexual dimorphism in size [43] and mercury accumulation [40]. In 5 of the 7 studies [31,34,38-40], methylmercury concentrations in muscle (ppm in wet tissue) were reported, which is also important because, unlike for tunas (again), methylmercury may be only a minor portion of the total mercury in muscle and other tissues of blue marlin [31]. Data were gathered directly from tables [31,32,38-40], or were contributed by the original authors $[34,35]$. Quality assurance/ quality control procedures and results for total mercury analyses
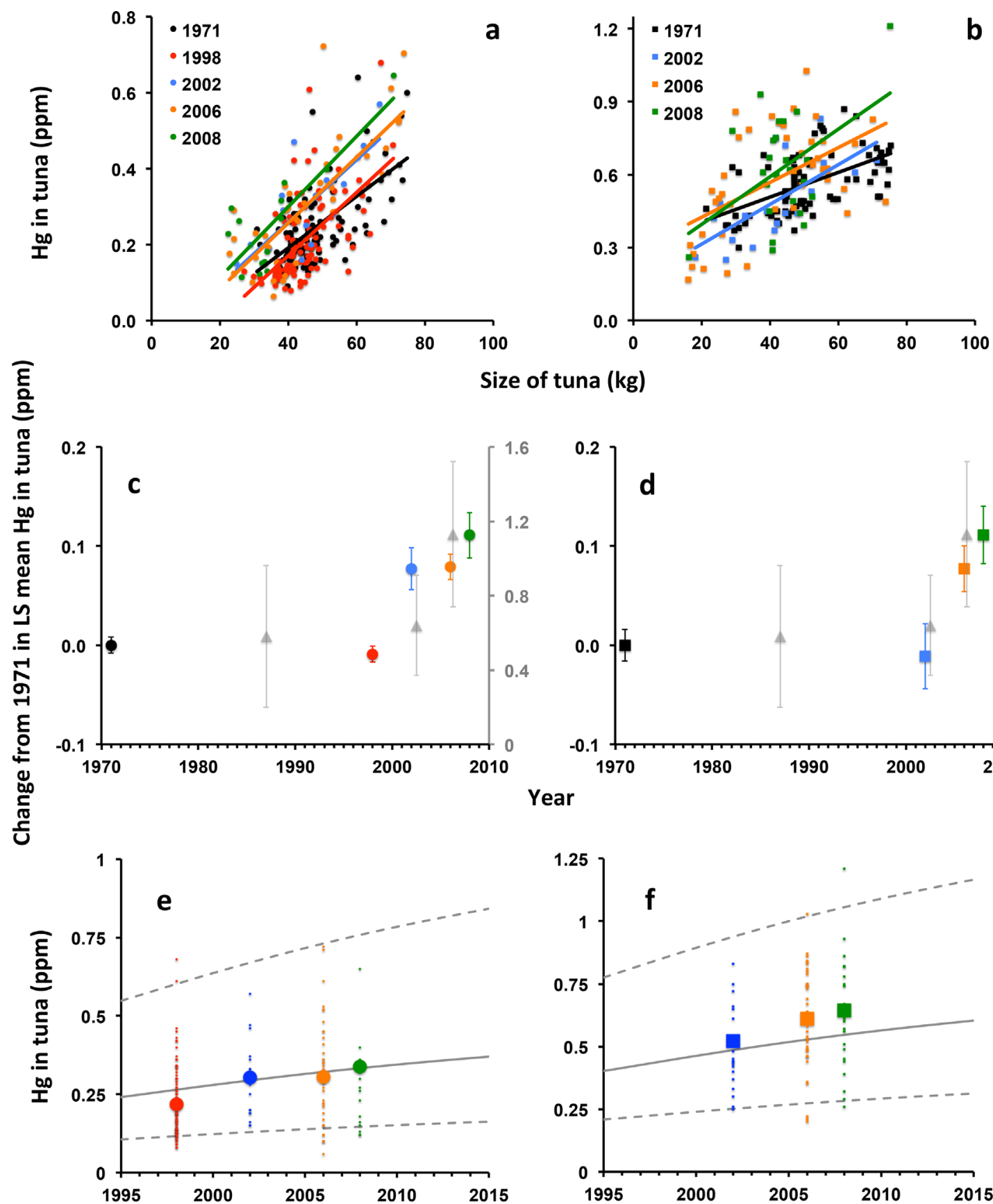

Size of tuna $(\mathrm{kg})$
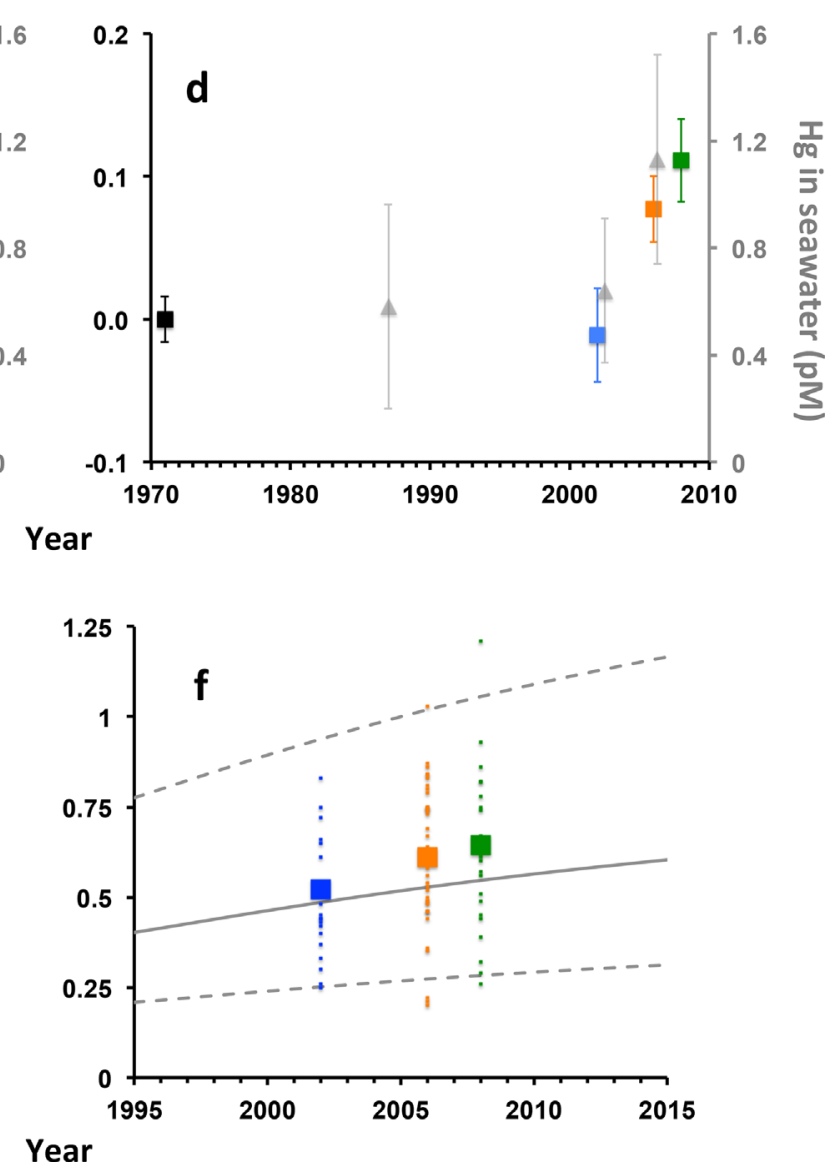

Figure 1. Mercury (Hg) in yellowfin tuna (circles; $\mathbf{a}, \mathbf{c}$, and $\mathbf{e}$ ) and bigeye tuna (squares; $\mathbf{b}, \mathbf{d}$, and $\mathbf{f})$. Panels (a) and (b) show linear regressions of tuna size (kg) versus (total) $\mathrm{Hg}$ concentration (ppm) for 5 time periods: 1971 (black [31,32]), 1998 (red [33]), 2002 (blue [34]), 2006 (orange [35]), and 2008 (green [36]). See Table 1 for regression statistics. Panels (c) and (d) show the change from 1971 in least squares (LS) mean ( \pm standard error) of (total) Hg in tuna. Overlaid on the tuna data are average (total) $\mathrm{Hg}$ concentrations in seawater between $0 \mathrm{~m}$ and $1000 \mathrm{~m}$ depths in the eastern North Pacific Ocean [3], represented by gray triangles ( \pm standard deviation). Panels (e) and (f) compare least squares means of (total) $\mathrm{Hg}$ in tuna (large circles and squares) and data from each individual tuna (small circles and squares) with modeled temporal trends for (total) $\mathrm{Hg}$ in tuna. See text for description of models. Solid gray lines represent models run with average $\delta^{15} \mathrm{~N}$ values, for each species, from Choy [47]; dashed gray lines represent averages \pm 1 standard deviation. 
for Rivers et al. [31] and Thieleke [32] and for Brooks [34] and Kaneko and Ralston [35] were summarized in Drevnick et al. [18] and in the present study, respectively. For Schultz et al. [38], Schultz and Crear [39], and Unninayar and Ito [40], digestions and analyses were performed as described by Rivers et al. [31]; but none of these studies described quality assurance/quality control procedures and results.

The data available for blue marlin do not allow for a fair comparison among years, because mercury concentrations covary with size and sex, and sex was identified (or reported) in only 3 of 7 studies. See the Results and Discussion section for further information.

Size (mass) of fish is important for interpreting changes in mercury concentrations with time, but among data sources, descriptions are lacking for the form of the fish when weighed. Before December 2004, "most of the pelagic catch in Hawaii was landed whole" [44], and we assume fish were weighed whole. After December 2004, US seafood safety regulations required that catches be landed gilled and gutted. Kaneko and Ralston [35] obtained tissue samples for their study from the Honolulu Fish Auction in 2006 and reported masses of gilled and gutted fish. We converted gilled and gutted masses to whole masses of yellowfin tuna and bigeye tuna according to the nonlinear models of Langley et al. [45] and of blue marlin with a conversion factor (1.25) from Ito [46]. Choy et al. [36] obtained tissue samples from yellowfin tuna, bigeye tuna, and blue marlin in 2008 collected by US National Oceanic and Atmospheric Administration (NOAA) fishery observers aboard commercial fishing vessels or from recreational boat captains. Because it is not indicated otherwise, we assume the masses in Choy et al. [36] for these species are from whole fish.

We used biomagnification models to simulate temporal trends in mercury concentrations of yellowfin tuna, bigeye tuna, and blue marlin, with which we compared empirical data. The models are based on the equation

$$
\log _{10}[\mathrm{Hg}]=\delta^{15} \mathrm{~N}(b)+a
$$

where $a$ and $b$ are the intercept and slope of a simple linear regression between nitrogen isotope composition $\left(\delta^{15} \mathrm{~N}\right.$; independent) and $\log 10$-transformed mercury concentrations $\left(\log _{10}[\mathrm{Hg}]\right.$; dependent) of a food web. Choy [47] reported $\delta^{15} \mathrm{~N}$ values and mercury concentrations from organisms in the North Pacific near Hawaii, sampled in 2009 to 2012, and from these data we constructed models for an epipelagic food web (includes yellowfin tuna and blue marlin; $a=0.40, b=0.21$ ) and an upper mesopelagic food web (includes bigeye tuna; $a=0.38, b=0.22$ ). To run the 2 models through time (1995-2015), slopes were kept constant (because there was no reason to suggest otherwise), and intercepts, which can be considered estimates of mercury incorporated at the base of the food webs [48], were adjusted according to modeled mercury concentrations in water [3]. Means and standard deviations of $\delta^{15} \mathrm{~N}$ values for yellowfin tuna $(10.2 \pm 1.7 \%$; $n=43)$, bigeye tuna $(10.8 \pm 1.3 \% \circ ; n=42)$, and blue marlin $(11.8 \pm 1.9 \%$; $n=7$ ) were also taken from Choy [47].

\section{RESULTS AND DISCUSSION}

\section{Yellowfin tuna and bigeye tuna}

For both tuna species and for each year of sampling, mercury concentration increased with size (Figure 1a and b). Summary statistics for linear regressions are given in Table 1.
The ANCOVA performed for each tuna species indicated that mercury concentrations significantly differ among years, with a trend of increasing concentration with time. Analysis of covariance is a 2-step process, with the first step testing whether slopes of regression lines are parallel. For both species, slopes of the regressions between mercury concentration and size were not statistically different among time periods (yellowfin tuna: $F_{4,278}=0.775, \quad p=0.542 ; \quad$ bigeye tuna: $F_{3,164}=1.15$, $p=0.330$ ), allowing us to proceed to the second step, removing the interaction term (size $\times$ year) and testing for difference in intercepts. For both species, intercepts (i.e., mercury concentrations at $x=0$ ) were statistically different among time periods (yellowfin tuna: $F_{4,282}=14.9, p<0.001$; bigeye tuna: $\left.F_{3,167}=5.48, p=0.001\right)$. For yellowfin tuna, a Tukey's HSD test found that least-squares means ( \pm standard error) of mercury concentrations from $2002(0.304 \pm 0.021 \mathrm{ppm}), 2006$ $(0.306 \pm 0.013 \mathrm{ppm})$, and $2008(0.338 \pm 0.024 \mathrm{ppm})$ were greater than from $1971(0.227 \pm 0.008 \mathrm{ppm})$ and 1998 $(0.218 \pm 0.008 \mathrm{ppm})$. For bigeye tuna, a Tukey's HSD test found that least-squares means ( \pm standard error) of mercury concentrations from $2006(0.610 \pm 0.022 \mathrm{ppm})$ and 2008 $(0.644 \pm 0.029 \mathrm{ppm}) \quad$ were greater than from 1971 $(0.533 \pm 0.016 \mathrm{ppm}), \quad$ whereas that from 2002 $(0.522 \pm 0.033 \mathrm{ppm})$ was less than 2008 and equivalent to 1971 and 2006. Least-squares means can be considered sizeadjusted means, because the ANCOVA adjusts group (year) means of the dependent variable (mercury concentration) by controlling for the effect of the covariate (size).

When the 2 tuna species are compared, mercury concentrations tend to be greater in bigeye tuna than in yellowfin tuna. Mercury is subject to biomagnification (i.e., an increase in concentration with trophic level), and bigeye tuna occupy a higher trophic level than yellowfin tuna [47]. In terms of regulatory guidelines, mercury concentrations in both species rarely exceed the US Food and Drug Administration (FDA) action level of $1 \mathrm{ppm}$ methylmercury in the edible portion (for the reduced data sets used in the present study, 0 of 288 yellowfin tuna and 2 of 172 bigeye tuna exceeded this value) and regularly exceed the US Environmental Protection Agency (USEPA) fish tissue residue criterion of $0.3 \mathrm{ppm}$ methylmercury (for the reduced data sets used in the present study, 73 of 288 yellowfin tuna and 160 of 172 bigeye tuna exceeded this value). Note that for all tuna species, it can be assumed that methylmercury constitutes "virtually all (>95\%)" [49] of the total mercury in muscle tissue. The FDA action level is defined as "a limit at or above which FDA will take legal actions to remove products from the market" [50], and according to the limit and the data shown, no action should be taken. The USEPA

Table 1. Summary statistics for linear regressions of size (mass, in kg) versus (total) mercury concentration (ppm in wet tissue) in yellowfin tuna and bigeye tuna caught near Hawaii

\begin{tabular}{lcccccc}
\hline Species & Year & No. & Slope & Intercept & $r^{2}$ & $p$ \\
\hline Yellowfin tuna & 1971 & 111 & 0.007 & -0.080 & 0.413 & $<0.001$ \\
& 1998 & 104 & 0.008 & -0.162 & 0.375 & $<0.001$ \\
& 2002 & 17 & 0.008 & -0.071 & 0.583 & $<0.001$ \\
Bigeye tuna & 2006 & 42 & 0.009 & -0.089 & 0.605 & $<0.001$ \\
& 2008 & 14 & 0.009 & -0.072 & 0.656 & $<0.001$ \\
& 1971 & 85 & 0.005 & 0.304 & 0.322 & $<0.001$ \\
& 2002 & 19 & 0.008 & 0.150 & 0.466 & 0.001 \\
& 2006 & 44 & 0.007 & 0.281 & 0.293 & $<0.001$ \\
& 2008 & 24 & 0.010 & 0.200 & 0.202 & 0.028 \\
\hline
\end{tabular}




\section{Female Male Unknown}
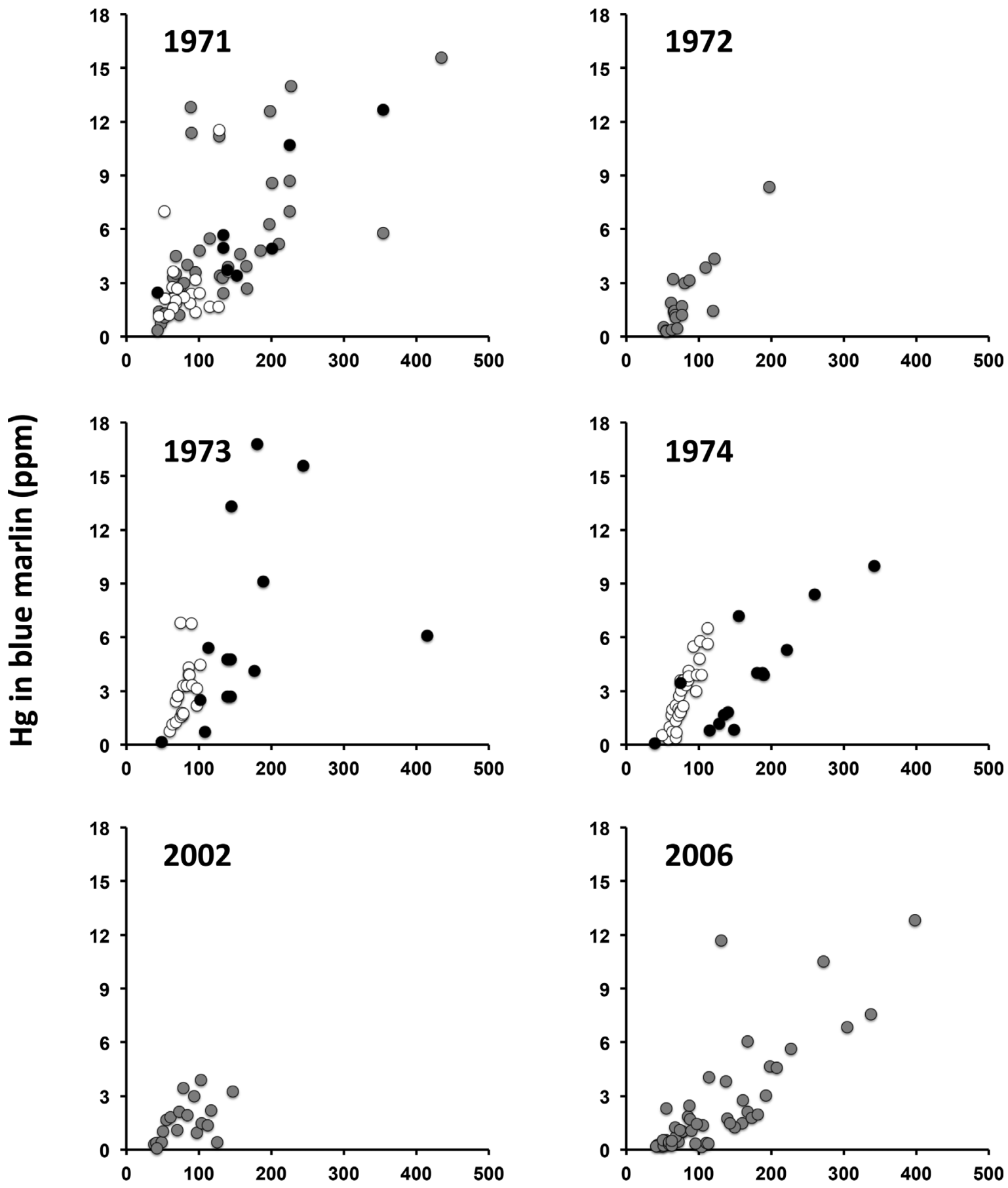

\section{Size of blue marlin $(\mathrm{kg})$}

Figure 2. Scatterplots of size (kg) and (total) mercury (Hg) concentration (ppm) in blue marlin from 1971 [31,32], 1972 [38], 1973 [39], 1974 [40], 2002 [34], and 2006 [35]. Black and white filled circles are for females and males, respectively. Gray filled circles are for blue marlin of unidentified or unreported (unknown) sex.

fish tissue residue criterion is the "maximum advisable concentration of methylmercury in freshwater and estuarine fish and shellfish tissue to protect consumers of fish and shellfish among the general population" [51]. This criterion, pursuant to the US Clean Water Act, is intended to be the basis for US states and tribes to manage mercury inputs to surface waters. Although the USEPA fish tissue residue criterion does not apply to tuna species, because tuna are marine fish and the Clean Water Act does not extend offshore, least-squares means of mercury concentrations of yellowfin tuna have increased from below the criterion $(1971,1998)$ to above the criterion $(2002,2006,2008)$. Because the concentrations exceed this criterion from 2002 
onward, consumers of yellowfin tuna and bigeye tuna caught in the North Pacific are not protected from adverse effects of mercury.

The present compilation and reanalysis of data reinforces the conclusion of Drevnick et al. [18] that mercury concentrations in tuna are increasing in the North Pacific as a result of anthropogenic loadings of mercury. Mercury delivered via atmospheric transport and deposition from natural and anthropogenic sources and via lateral flow of waters from the coast of the western North Pacific Ocean is causing increased mercury concentrations in waters of the central and eastern North Pacific Ocean [3,52]. The temporal trend in mercury concentrations in waters between $0 \mathrm{~m}$ and $1000 \mathrm{~m}$ depths $(+3 \%)$ yr during 1995-2006) [3] is mirrored by the changes in mercury concentrations in yellowfin tuna $(+5.5 \pm 1.6 \% / y r$ during 1998-2008) and bigeye tuna $(+3.9 \pm 2.1 \% / \mathrm{yr}$ during 2002-2008) (Figure 1c and d). Furthermore, mercury data from each individual tuna and the least-squares mean for each year for each species are accurately predicted by biomagnification models that are built on data independent of this synthesis [47] and use modeled mercury concentrations in water [3] to adjust the amount of mercury incorporated at the base of (epipelagic and mesopelagic) food webs (Figure 1e and f). The empirical data indicate inflection points where mercury concentrations shift from steady state to increasing, at 2002 for water and bigeye tuna and at 1998 for yellowfin tuna. It seems unlikely, however, that there was a discrete time point during the late 20th century or early $21 \mathrm{st}$ century when mercury concentrations began to increase. Instead, limited sampling (in both sample sizes and the number of years sampled) and variability in mercury concentrations (within years) preclude the discernment of subtle, gradual changes. The geophysical evidence, from sediment cores from lakes along the North American Pacific coast, points to a continuous increase in rates of atmospheric mercury deposition post 1850 [53]. Sunderland et al. [3] suggested that long-term changes in mercury concentrations in water may be underestimated because of seasonal variability. Water samples were collected in spring (2002, 2006) and summer (1987). During summer, the water column is enriched in mercury, compared with other seasons [54]. Accordingly, the model constructed by Sunderland et al. [3] projects a continuous increase in mercury concentrations in water. The record from black-footed albatross [19] also suggests that the increase in mercury is continuous over the period 1880 to 2002, but is at an elevated rate after 1990 .

The difference in the timing of the inflection points for yellowfin tuna (1998) and bigeye tuna (2002) may be an artifact of sampling error (no bigeye tuna sampled in 1998; sample sizes low in 2002) or because of the contrasting biology and ecology of the 2 species. Kwon et al. [55] determined the time that socalled new mercury is at steady state in Pacific bluefin tuna (Thunnus orientalis) to be $>1070 \mathrm{~d}$. Time to steady state depends on metabolic rate (inverse relationship), which in turn is (directly) related to temperature [56]. At a given temperature, bigeye tuna have lower metabolic rates [57] and likely a longer time to steady state (for mercury), compared with yellowfin tuna. Furthermore, bigeye tuna have lower average body temperatures than yellowfin tuna, because the former inhabit deeper (and colder) waters than the latter [58]. Lastly, yellowfin tuna are resident in Hawaii year round, but bigeye tuna exhibit a north-south migration, spending the winter months of the northern hemisphere in the Equatorial Pacific [59-63]. There has been no detectable increase in mercury concentrations in water over time in the Equatorial Pacific [64], in contrast to the
North Pacific. These 3 factors (metabolism, temperature, migration) could contribute to a delay in the inflection point of the bigeye tuna record, compared with that for yellowfin tuna.

\section{Blue marlin}

For blue marlin for each year of sampling, mercury concentrations were positively related to size (Figure 2). Summary statistics of linear regressions (not shown in Figure 2) of $\log _{10}$-transformed data are given in Table 2. $\log _{10}$ transformations were necessary for both the independent and dependent variables to meet assumptions of linear regression. Also note that data sets were not restricted to a size range common to all years, as for the tuna species, because an amongyear comparison (e.g., ANCOVA) was not performed (see the following paragraphs).

For any given size of blue marlin that overlaps between sexes, mercury concentrations tend to be higher in males than females, although the largest individuals are all females and have the highest mercury concentrations (Figure 2). Between-sex comparisons with data from 1973 [39] and 1974 [40], the only $2 \mathrm{yr}$ in which sex was identified in all individuals, are illustrative. Linear regressions by year and by sex (also in Table 2) predict mercury concentrations of $4.70 \mathrm{ppm}$ (1973) and $5.16 \mathrm{ppm}$ (1974) for a $100-\mathrm{kg}$ male (approximately the 90th percentile for size for males) and $1.77 \mathrm{ppm}$ (1973) and $1.09 \mathrm{ppm}$ (1974) for a 100-kg female (approximately the 10th percentile for size for females). Sex differences in mercury concentrations have been noted for other fish species (but not for tuna), and, in general, males may have higher mercury concentrations than females because the former tend to ingest more mercury than the latter, as a result of a higher rate of energy expenditure [65]. The maximum mercury concentration for males was $6.8 \mathrm{ppm}$, but 7 females exceeded this value, with mercury concentrations of 7.2, 8.4, 9.1, 10.0, 13.3, 15.6 , and $16.8 \mathrm{ppm}$. Presumably, mercury concentrations are highest in the largest individuals because these fish eat the largest prey items that are highest in mercury.

We could not fairly compare mercury concentrations in blue marlin among years with ANCOVA or another appropriate model (e.g., the Johnson-Neyman technique). It is apparent that mercury concentrations in blue marlin covary with size and sex; and from the 3 studies that reported sex, unequal numbers of males and females were sampled among years. Performing an ANCOVA as above, with size as the single covariate, would yield ambiguous results; that is, a treatment (year) effect could not be distinguished from a sex effect. The appropriate statistical model would incorporate both size and sex as

Table 2. Summary statistics for linear regressions of $\log _{10}$-transformed size (mass, in $\mathrm{kg}$ ) versus $\log _{10}$-transformed (total) mercury concentration (ppm in wet tissue) in blue marlin caught near Hawaii

\begin{tabular}{lcccccr}
\hline Year & & No. & Slope & Intercept & $r^{2}$ & \multicolumn{1}{c}{$p$} \\
\hline \multirow{2}{*}{1971} & All & 69 & 0.995 & -1.48 & 0.510 & $<0.001$ \\
& Males & 21 & 0.418 & -0.415 & 0.058 & 0.291 \\
& Females & 8 & 0.776 & -0.969 & 0.705 & 0.009 \\
1972 & All (sex not identified) & 19 & 2.12 & -3.85 & 0.572 & $<0.001$ \\
1973 & All & 35 & 1.38 & -2.30 & 0.428 & $<0.001$ \\
& Males & 21 & 2.57 & -4.48 & 0.415 & 0.002 \\
& Females & 14 & 2.02 & -3.79 & 0.561 & 0.002 \\
1974 & All & 46 & 1.31 & -2.23 & 0.377 & $<0.001$ \\
& Males & 32 & 3.39 & -6.06 & 0.692 & $<0.001$ \\
& Females & 14 & 1.95 & -3.86 & 0.695 & $<0.001$ \\
2002 & All (sex not identified) & 19 & 1.58 & -2.93 & 0.378 & 0.005 \\
2006 & All (sex not identified) & 50 & 1.68 & -3.31 & 0.659 & $<0.001$ \\
& & & & & &
\end{tabular}


covariates [66], but that is not possible because sex was not identified or reported in 4 of 7 studies, including both of the recent studies $[34,35]$.

Mercury concentrations in blue marlin are elevated compared with yellowfin tuna and bigeye tuna, as well as other fish species. For blue marlin from all years $(n=238)$, minimum, maximum, mean, and median concentrations of (total) mercury were $0.060 \mathrm{ppm}, 16.8 \mathrm{ppm}, 3.33 \mathrm{ppm}$, and $2.40 \mathrm{ppm}$, respectively. Methylmercury, measured in a subset of blue marlin $(n=130)$, had minimum, maximum, mean, and median concentrations of $0.020 \mathrm{ppm}, 1.79 \mathrm{ppm}, 0.518 \mathrm{ppm}$, and $0.425 \mathrm{ppm}$, respectively. Note that the mean, median, and maximum concentrations of (total) mercury concentrations exceeded by at least 2 times that of all other fishes in the FDA Monitoring Program [67], including fishes (tilefish from the Gulf of Mexico, shark, swordfish, king mackerel) that a joint USEPA-FDA advisory cautions to avoid eating [68]. Because the FDA action level is $1 \mathrm{ppm}$ methylmercury, and in most (120/ 130) blue marlin methylmercury constitutes less than half of total mercury (Figure 3c), few (13/130) blue marlin exceed this value. In contrast, 74\% (96/130) of blue marlin exceed the USEPA fish tissue residue criterion, although (again) criteria developed for the Clean Water Act pertain only to freshwater and estuarine fish. Furthermore, methylmercury concentrations are within the range of values $(0.5-1.2 \mathrm{ppm})$ known to elicit toxic effects in fish ("effects on biochemical processes, damage
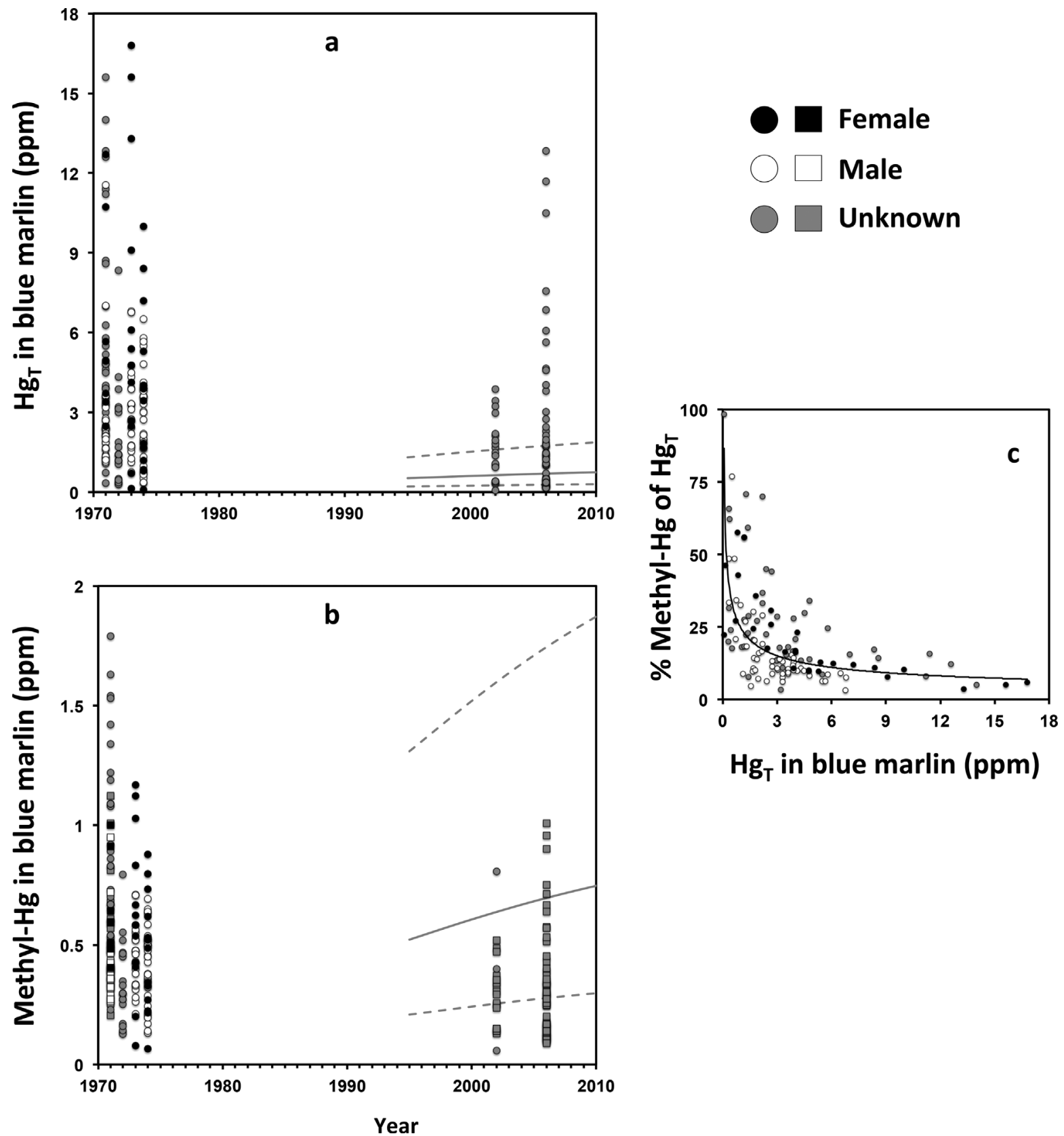

$\mathrm{Hg}_{\mathrm{T}}$ in blue marlin (ppm)

Figure 3. Comparison of concentrations ( $\mathrm{ppm})$ of total mercury $\left(\mathrm{Hg}_{\mathrm{T}} ; \mathbf{a}\right)$ and methylmercury (methyl- $\left.\mathrm{Hg} ; \mathbf{b}\right)$ in blue marlin with modeled temporal trends for $\mathrm{Hg}_{\mathrm{T}}$ in blue marlin. Black and white filled symbols are for females and males, respectively. Gray filled symbols are for blue marlin of unidentified or unreported (unknown) sex. Circles represent empirical data. Squares (b only) represent predicted values from the relationship $\left(y=24.6 x^{-0.447}\right)$ between $\mathrm{Hg}_{\mathrm{T}}$ and percentage of methyl- $\mathrm{Hg}$ that is $\mathrm{Hg}_{\mathrm{T}}$, shown in (c). For description of model, see text. The solid gray line represents model run with average $\delta^{15} \mathrm{~N}$ value for blue marlin, from Choy [47]; dashed gray lines represent the average \pm 1 SD. 
to cells and tissues, and reduced reproduction" [69]), and this selective force appears to have elicited the evolution of a detoxification pathway (see the next paragraph).

Blue marlin are apex marine predators and thus are exposed to significant amounts of methylmercury in prey items, but (total) mercury concentrations are elevated compared with other fishes at a similar trophic level because of an apparent ability to demethylate methylmercury and sequester inorganic mercury in their muscle tissue. The epipelagic biomagnification model that accurately predicted (total) mercury concentrations in yellowfin tuna grossly underperformed for blue marlin (Figure 3a). Modeled (total) mercury concentrations for blue marlin (at a mean \pm standard deviation [SD] of $\delta^{15} \mathrm{~N}$ value of $11.8 \pm 1.9 \%$ ) for the period 1995 to 2010 range from $0.522 \mathrm{ppm}$ to $0.746 \mathrm{ppm}$. Fifty-five percent (130/238) of measured (total) mercury concentrations exceed the upper bound (i.e., mean $\delta^{15} \mathrm{~N}$ value $+1 \mathrm{SD} ; 2.13 \mathrm{ppm}$ in 2010) of the model. In contrast, methylmercury concentrations are generally within the lower (i.e., mean $\delta^{15} \mathrm{~N}$ value - $1 \mathrm{SD}$; 0.208 ppm in 1995) and upper bounds of the model (Figure $3 b$ ). It is our hypothesis that methylmercury in blue marlin constitutes a "fast pool" of mercury that is ingested, accumulates in tissues, and is demethylated to inorganic mercury. The "slow pool" is the resulting inorganic mercury that is sequestered in detoxified insoluble subcellular fractions $[70,71]$, that is, granules and heat-stable peptides and proteins [72,73]. It is the sequestration of inorganic mercury that results in exceptionally high (total) mercury concentrations in blue marlin. Many species of fish are known to store inorganic mercury in organs associated with detoxification-notably, liver, kidney, and spleen [74]—but to our knowledge, only blue marlin store inorganic mercury in muscle tissue.

\section{Uncertainties and future directions}

The data used in the present synthesis highlight the difficulty in discerning clear temporal trends in mercury concentrations in open ocean fish. The ANCOVAs performed with data from yellowfin tuna and bigeye tuna unequivocally show increases in mercury concentrations with time, but limited sampling (within and among years) and variability in mercury concentrations (within years) confuse our understanding. Are the increases in mercury concentrations in yellowfin tuna and bigeye tuna continuous, as models suggest, or discrete, as the data suggest? Physiological differences among (tunas vs blue marlin) and within (male vs female) species also introduce uncertainty, if differences are not understood (e.g., detoxification) or accounted for in sampling design (e.g., sex). It may very well be that total mercury and methylmercury concentrations are declining in blue marlin, but the compiled data set does not allow for a robust analysis. Furthermore, spatial complexity within (e.g., North Pacific vs Equatorial Pacific) and among ocean basins for migratory species (e.g., bigeye tuna) complicates interpretations. Bonito et al. [75] reported that, globally, mercury concentrations in ocean fish (842 species) declined during 1969 to 2012 by approximately $1 \% / y r$, but their analysis was heavily skewed toward fish from the Atlantic Ocean, where mercury concentrations are declining; fish from the Mediterranean Sea, Indian Ocean, and Pacific Ocean showed no trend. Likewise, Davis et al. [76] reported no trend in mercury concentrations in fish (109 species) during 1985 to 2014 from the US Pacific coast, but the authors stressed that their analysis was based on strikingly little available data and that "expanded and continued monitoring would be of great value in characterizing methymercury exposure and tracking changes in contamination."
In the North Pacific Ocean, efforts to evaluate the effectiveness of the Minamata Convention on mercury concentrations in environmental media should leverage and add to historic data sets, including those for yellowfin tuna and bigeye tuna. Other media with data sets that comprise more than one time period-and (may) show changes in mercury concentrations over time-include water [3,54], other fishes, black-footed albatross [19], and human umbilical cord blood [77,78]. Other fishes include Pacific cod (G. macrocephalus) in Alaskan waters $[79,80]$ and albacore tuna (Thunnus alalunga) off the US Pacific coast $[81,82]$, both of which (as for yellowfin tuna and bigeye tuna) are the basis for important capture fisheries in the North Pacific Ocean $[27,83]$. It would be advantageous for governments and the fishing industry to work together to monitor mercury in (at least) these 4 fish species, as an efficient means to track temporal trends and to estimate exposure to fish, wildlife, and humans. Human consumers of fish are generally aware of risks associated with mercury, particularly for tuna; mercury devalues fisheries; and fishes low in mercury such as Pacific troll-caught albacore tuna may have a perceived high value $[81,84]$.

Supplemental Data-The Supplemental Data are available on the Wiley Online Library at DOI: 10.1002/etc.3757.

Acknowledgment-We thank J. Kaneko for contributing data from Kaneko and Ralston [35]. P.E. Drevnick was supported by the University of Michigan. Data from Brooks [34] were from fish sampled by the United Fishing Agency, and C. Callahan, G. Takebayashi, and M. Sutterfield, Hawaii Department of Health, contributed to that study. M. Horgan and 3 anonymous reviewers provided constructive comments on an earlier draft of the manuscript. P.E. Drevnick and B.A. Brooks declare no competing financial interests or any other conflicts of interest.

Data availability—Data are included as a supplement to the manuscript.

\section{REFERENCES}

1. Lamborg $\mathrm{CH}$, Hammerschmidt CR, Bowman KL, Swarr GJ, Munson KM, Ohnemus DC, Lam PJ, Heimbürger L-E, Rijkenberg MJA, Saito MA. 2014. A global ocean inventory of anthropogenic mercury based on water column measurements. Nature 512:65-68.

2. De Simone F, Gencarelli CN, Hedgecock IM, Pirrone N. 2016 A modeling comparison of mercury deposition from current anthropogenic mercury emission inventories. Environ Sci Technol 50:5154-5162.

3. Sunderland EM, Krabbenhoft DP, Moreau JW, Strode SA, Landing WM. 2009. Mercury sources, distribution, and bioavailability in the North Pacific Ocean: Insights from data and models. Global Biogeochem Cycles 23:GB2010.

4. Soerensen AL, Jacob DJ, Streets DG, Witt MLI, Ebinghaus R, Mason RP, Andersson M, Sunderland EM. 2012. Multi-decadal decline of mercury in the North Atlantic atmosphere explained by changing subsurface seawater concentrations. Geophys Res Lett 39:L21810.

5. Zhang Y, Jacob DJ, Horowitz HM, Chen L, Amos HM, Krabbenhoft DP, Slemr F, St. Louis VL, Sunderland EM. 2016. Observed decrease in atmospheric mercury explained by global decline in anthropogenic emissions. Proc Natl Acad Sci USA 113:526-531.

6. Fisher JA, Jacob DJ, Soerensen AL, Amos HM, Steffen A, Sunderland EM. 2012. Riverine source of Arctic Ocean mercury inferred from atmospheric observations. Nat Geosci 5:499-504.

7. Soerensen AL, Jacob DJ, Schartup AT, Fisher JA, Lehnherr I, St. Louis VL, Heimbürger L-E, Sonke JE, Krabbenhoft DP, Sunderland EM. 2016. A mass budget for mercury and methylmercury in the Arctic Ocean. Global Biogeochem Cycles 30:560-575.

8. Cossa D, Averty B, Pirrone N. 2009. The origin of methylmercury in open Mediterranean waters. Limnol Oceanogr 54:837-844.

9. Lehnherr I, St. Louis VL, Hintelmann H, Kirk J. 2011. Methylation of inorganic mercury in polar marine waters. Nat Geosci 4:298-302.

10. Munson KM. 2014. Transformations of mercury in the marine water column. PhD theis. Massachusetts Institute of Technology and Woods Hole Oceanographic Institution, Cambridge, MA, USA. 
11. Blum JD, Popp BN, Drazen JC, Choy CA, Johnson MW. 2013. Methylmercury production below the mixed layer in the North Pacific Ocean. Nat Geosci 6:879-884.

12. Bergquist BA, Blum JD. 2007. Mass-dependent and -independent fractionation of $\mathrm{Hg}$ isotopes by photoreduction in aquatic systems. Science 318:417-420.

13. Masbou J, Point D, Guillou G, Sonke JE, Lebreton B, Richard. 2015. Carbon stable isotope analysis of methylmercury toxin in biological materials by gas chromatography isotope ratio mass spectrometry. Anal Chem 87:11732-11738.

14. Cross FA, Evans DW, Barber RT. 2015. Decadal declines of mercury in adult bluefish (1972-2011) from the Mid-Atlantic coast of the U.S.A. Environ Sci Technol 49:9064-9072.

15. Lee C-S, Lutcavage ME, Chandler E, Madigan DJ, Cerrato RM, Fisher NS. 2016. Declining mercury concentrations in bluefin tuna reflect reduced emissions to the North Atlantic Ocean. Environ Sci Technol 50:12825-12830

16. Murray MS, McRoy CP, Duffy LK, Hirons AC, Schaal JM, Trocine RP, Trefry J. 2015. Biogeochemical analysis of ancient Pacific cod bone suggests $\mathrm{Hg}$ bioaccumulation was linked to paleo sea level rise and climate change. Front Environ Sci 3:1-8.

17. Jaffe DA, Prestbo E, Swartzendruber P, Weiss-Penzias P, Kato S, Takami A, Hatakeyama S, Kajii Y. 2005. Export of atmospheric mercury from Asia. Atmos Environ 39:3029-3038.

18. Drevnick PE, Lamborg CH, Horgan MJ. 2015. Increase in mercury in Pacific yellowfin tuna. Environ Toxicol Chem 34:931-934.

19. Vo A-TE, Bank MS, Shine JP, Edwards SV. 2011. Temporal increase in organic mercury in an endangered pelagic seabird assessed by centuryold museum specimens. Proc Natl Acad Sci U S A 108:7466-7471.

20. Dietz R, Riget FF, Boertmann D, Sonne C, Olsen MT, Fjeldså J, Falk K, Kirkegaard M, Egevang C, Asmund G, Wille F, Møller S. 2006. Time trends of mercury in feathers of West Greenland birds of prey during 1851-2003. Environ Sci Technol 40:5911-5916.

21. Dietz R, Riget F, Born EW, Sonne C, Grandjean P, Kirkegaard M, Olsen MT, Asmund G, Renzoni A, Baagøe H, Andreasen C. 2006. Trends in mercury in hair of Greenlandic polar bears (Ursus maritimus) during 1892-2001. Environ Sci Technol 40:1120-1125.

22. Dietz R, Outridge PM, Hobson KA. 2009. Anthropogenic contributions to mercury levels in present-day Arctic animals-A review. Sci Total Environ 407:6120-6131.

23. Dietz R, Born EW, Rigét F, Aubail A, Sonne C, Drimmie R, Basu N. 2011. Temporal trends and future predictions of mercury concentrations in Northwest Greenland polar bear (Ursus maritimus) hair. Environ Sci Technol 45:1458-1465.

24. Bond AL, Hobson KA, Branfireun BA. 2015. Rapidly increasing methyl mercury in endangered ivory gull (Pagophila eburnea) feathers over a 130 year record. Proc $R$ Soc B 282:20150032.

25. United Nations Environment Programme. 2013. Minamata Convention on Mercury. [cited 2017 February 01]. Available from: http://www. mercuryconvention.org/Portals/11/documents/Booklets/Minamata Convention on Mercury_booklet_English.pdf

26. International Seafood Sustainability Foundation. 2016. ISSF tuna stock status update, 2016: Status of the world fisheries for tuna. ISSF Technical Report 2016-05. International Seafood Sustainability Foundation, Washington, DC.

27. Galland G, Rogers A, Nickson A. 2016. Netting Billions: A Global Valuation of Tuna. The Pew Charitable Trusts, Philadelphia, PA, USA.

28. Sunderland EM. 2007. Mercury exposure from domestic and imported estuarine and marine fish in the U.S. seafood market. Environ Health Perspect 115:235-242.

29. Karimi R, Fitzgerald TP, Fisher NS. 2012. A quantitative synthesis of mercury in commercial seafood and implications for exposure in the United States. Environ Health Perspect 120:1512-1519.

30. Billfish Working Group. 2013. Stock assessment of blue marlin in the Pacific Ocean in 2013. Annex 13 of ISC13 Plenary Report. International Scientific Committee for Tuna and Tuna-like Species in the North Pacific Ocean, Busan, Republic of Korea.

31. Rivers JB, Pearson JE, Shultz CD. 1972. Total and organic mercury in marine fish. Bull Environ Contam Toxicol 8:257-266.

32. Thieleke JR. 1973. Mercury levels in five species of commercially important pelagic fish taken from the Pacific Ocean near Hawaii. MS thesis. University of Wisconsin-Madison, WI, USA.

33. Kraepiel AML, Keller K, Chin HB, Malcolm EG, Morel FMM. 2003. Sources and variations of mercury in tuna. Environ Sci Technol 37:5551-5558.

34. Brooks B. 2004. Mercury levels in tuna and other major commercial fish species in Hawaii. Proceedings, 2004 National Forum on Contaminants in Fish, San Diego, CA, USA, January 25-28, 2004, p 24.
35. Kaneko JJ, Ralston NVC. 2007. Selenium and mercury in pelagic fish in the central North Pacific near Hawaii. Biol Trace Elem Res 119: 242-254.

36. Choy CA, Popp BN, Kaneko JJ, Drazen JC. 2009. The influence of depth on mercury levels in pelagic fishes and their prey. Proc Natl Acad Sci U S A 106:13865-13869.

37. Bosch AC, O’Neill B, Sigge GO, Kerwath SE, Hoffman LC. 2016. Mercury accumulation in yellowfin tuna (Thunnus albacares) with regards to muscle type, muscle position and fish size. Food Chem 190:351-356.

38. Schultz CD, Crear D, Pearson JE, Rivers JB, Hylin JW. 1976. Total and organic mercury in the Pacific blue marlin. Bull Environ Contam Toxicol 15:230-234.

39. Schultz CD, Crear D. 1976. The distribution of total and organic mercury in seven tissues of the Pacific blue marlin, Makaira nigricans. Pacific Sci 30:101-107

40. Unninayar CS, Ito BM. 1975. Mercury in the Pacific blue marlin, Makaira nigricans. Southwest Fisheries Center Administrative Report 2H. Southwest Fisheries Center, National Marine Fisheries Service, NOAA, Honolulu, HI, USA.

41. Adams DH. 2004. Total mercury levels in tunas from offshore waters of the Florida Atlantic coast. Mar Pollut Bull 49:659-667.

42. Chen C-Y, Lai C-C, Chen K-S, Hsu C-C, Hung C-C, Chen M-H. 2014. Total and organic mercury concentrations in the muscles of Pacific albacore (Thunnus alalunga) and bigeye tuna (Thunnus obesus). Mar Pollut Bull 85:606-612.

43. Wilson CA, Dean JM, Prince ED, Lee DW. 1991. An examination of sexual dimorphism in Atlantic and Pacific blue marlin using body weight, sagittae weight, and age estimates. J Exp Mar Biol Ecol 151: 209-225.

44. Ito R. 2005. Review of product form conversion ratios for the Hawaii billfish catch. PIFCS Working Paper ISC/05/MAR\&SWO-WGs/3. Pacific Islands Fisheries Science Center, National Marine Fisheries Service, NOAA, Honolulu, HI, USA.

45. Langley A, Okamoto H, Williams P, Miyabe N, Bigelow K. 2006. A summary of data available for the estimation of conversion factors (processed to whole fish weights) for yellowfin and bigeye tuna WCPFC-SC2-2006/ME IP-3. Western and Central Pacific Fisheries Commission, Kolonia, Federated States of Micronesia.

46. Ito RY. 2013. U.S. commercial fisheries for marlins in the North Pacific Ocean. PIFCS Working Paper WP-13-001. Pacific Islands Fisheries Science Center, NOAA Fisheries Service, Honolulu, HI, USA.

47. Choy CA. 2013. Pelagic food web connectivity in the North Pacific subtropical gyre: A combined perspective from multiple biochemical tracers and diet. $\mathrm{PhD}$ thesis. University of Hawai'i at Manoa, HI, USA.

48. Lavoie RA, Jardine TD, Chumchal MM, Kidd KA, Campbell LM. 2013. Biomagnification of mercury in aquatic food webs: A worldwide meta-analysis. Environ Sci Technol 47:13385-13394.

49. Bloom NS. 1992. On the chemical form of mercury in edible fish and marine invertebrate tissue. Can J Fish Aquat Sci 49:1010-1017.

50. US Food and Drug Administration. 2000. Guidance for industry: Action levels for poisonous or deleterious substances in human food and animal feed. [cited 2017 February 01]. Available from: http://www. fda.gov/Food/GuidanceRegulation/

GuidanceDocumentsRegulatoryInformation/ucm077969.htm

51. US Environmental Protection Agency. 2001. Water quality criterion for the protection of human health: Methylmercury. EPA 823/F-01/001. Washington, DC.

52. Hammerschmidt CR, Bowman KL. 2012. Vertical methylmercury distribution in the subtropical North Pacific Ocean. Mar Chem 132-133:77-82.

53. Drevnick PE, Cooke CA, Barraza D, Blais JM, Coale KH, Cumming BF, Curtis CJ, Das B, Donahue WF, Eagles-Smith CA, Engstrom DR, Fitzgerald WF, Furl CV, Gray JE, Hall RI, Jackson TA, Laird KR, Lockhart WL, Macdonald RW, Mast MA, Mathieu C, Muir DCG, Outridge PM, Reinemann SA, Rothenberg SE, Ruiz-Fernández AC, St. Louis VL, Sanders RD, Sanei H, Skierszkan EK, Van Metre PC, Veverica TJ, Wiklund JA, Wolfe B. 2016. Spatiotemporal patterns of mercury accumulation in lake sediments of western North America. Sci Total Environ 568:1157-1170.

54. Laurier F, Mason RP, Gill G, Whalin L. 2004. Mercury distribution in the North Pacific Ocean: 20 years of observations. Mar Chem 90:319.

55. Kwon SY, Blum JD, Madigan DJ, Block BA, Popp BN. 2016. Quantifying mercury isotope dynamics in captive Pacific bluefin tuna (Thunnus orientalis). Elementa 4:000088.

56. Korsmeyer KE, Dewar H. 2001. Tuna metabolism and energetics. In Block BA, Stevens ED, eds, Tuna: Physiology, Ecology, and Evolution Academic, San Diego, CA, USA, pp 35-78. 
57. Bushnell PG, Brill RW, Bourke RE. 1990. Cardiorespiratory responses of skipjack tuna (Katsuwonus pelamis), yellowfin tuna (Thunnus albacares), and bigeye tuna (Thunnus obesus) to acute reductions of ambient oxygen. Can J Zool 68:1857-1865.

58. Graham JB, Dickson KA. 2004. Tuna comparative physiology. J Exp Biol 207:4015-4024.

59. Itano DG, Holland KN. 2000. Movement and vulnerability of bigeye (Thunnus obesus) and yellowfin tuna (Thunnus albacares) in relation to FADs and natural aggregation points. Aquat Living Resour 13:213-223.

60. Sibert JR, Musyl MK, Brill RW. 2003. Horizontal movements of bigeye tuna (Thunnus obesus) near Hawaii determined by Kalman filter analysis of archival tagging data. Fish Oceanogr 12:141-151.

61. Graham BS. 2008. Trophic dynamics and movements of tuna in the tropical Pacific Ocean inferred from stable isotope analyses. $\mathrm{PhD}$ thesis. University of Hawai'i at Manoa, HI, USA.

62. Hyder P, Bigelow K, Brainard R, Seki M, Firing J, Flament P. 2009. Migration and abundance of bigeye tuna (Thunnus obesus), and other pelagic species, inferred from catch rates and their relation to variations in the ocean environment. SOEST 09-02, JIMAR Contribution 09-371. School of Ocean and Earth Science and Technology, University of Hawai'i at Manoa, HI, USA.

63. Rooker JR, Wells RJD, Itano DG, Thorrold SR, Lee JM. 2016. Natal origin and population connectivity of bigeye and yellowfin tuna in the Pacific Ocean. Fish Oceanogr 25:277-291.

64. Munson KM, Lamborg CH, Swarr GJ, Saito MA. 2015. Mercury species concentrations and fluxes in the central Tropical Pacific Ocean. Global Biogeochem Cycles 29:656-676.

65. Madenjian CP, Rediske RR, Krabbenhoft DP, Stapanian MA, Chernyak SM, O'Keefe JP. 2016. Sex differences in contaminant concentrations in fish: A synthesis. Biol Sex Differ 7:42.

66. Underwood AJ. 1997. Experiments in Ecology: Their Logical Design and Interpretation Using Analysis of Variance. Cambridge University, Cambridge, UK.

67. US Food and Drug Administration. 2017. Mercury levels in commercial fish and shellfish (1990-2012). [cited 2017 February 01]. Available from: http://www.fda.gov/Food/FoodborneIllnessContamin ants/Metals/ucm115644.htm

68. US Environmental Protection Agency. 2017. Choose fish and shellfish wisely: What you need to know about mercury in fish and shellfish. [cited 2017 February 01]. Available from: http://www.epa.gov/choosefish-and-shellfish-wisely/what-you-need-to-know-about-mercury-fishand-shellfish

69. Sandheinrich MB, Wiener JG. 2011. Methylmercury in freshwater fish: Recent advances in assessing toxicity of environmentally relevant exposures. In Beyer WN, Meador JP, eds, Environmental Contaminants in Biota: Interpreting Tissue Concentrations, 2nd ed. CRC, Boca Raton, FL, USA, pp 169-192.
70. Barghigiani C, Pellegrini D, Carpene E. 1989. Mercury binding proteins in liver and muscle of flat fish from the northern Tyrrhenian Sea. Comp Biochem Physiol 94C:309-312.

71. Bebianno MJ, Santos C, Canário J, Gouveia N, Sena-Carvalho D, Vale C. 2007. Hg and metallothionein-like proteins in the black scabbardfish Aphanopus carbo. Food Chem Toxicol 45:1443-1452.

72. Onsanit S, Wang W-X. 2011. Sequestration of total and methyl mercury in different subcellular pools in marine caged fish. $J$ Hazard Mater 198:113-122.

73. Barst BD, Rosabal M, Campbell PGC, Muir DGC, Wang X, Köck G, Drevnick PE. 2016. Subcellular distribution of trace elements and liver histology of landlocked Arctic char (Salvelinus alpinus) sampled along a mercury contamination gradient. Environ Pollut 212:574-583.

74. Kidd K, Batchelar K. 2012. Mercury. In Wood CM, Farrell AP, Brauner CJ, eds, Fish Physiology, Vol 31B, Homeostasis and Toxicology of Non-Essential Metals. Elsevier, London, UK, pp 237-295.

75. Bonito LT, Hamdoun A, Sandin SA. 2016. Evaluation of the global impacts of mitigation on persistent, bioaccumulative and toxic pollutants in marine fish. PeerJ 4:e1573.

76. Davis JA, Ross JRM, Bezalel S, Sim L, Bonnema A, Ichikawa G, Heim WA, Schiff K, Eagles-Smith CA, Ackerman JT. 2016. Hg concentrations in fish from coastal waters of California and Western North America. Sci Total Environ 568:1146-1156.

77. Sato RL, Li GG, Shaha S. 2006. Antepartum seafood consumption and mercury levels in newborn cord blood. Am J Obstet Gynecol 194:1683-1688.

78. Soon R, Dye TD, Ralston NV, Berry MJ, Sauvage LM. 2014. Seafood consumption and umbilical cord blood mercury concentrations in a multiethnic maternal and child health cohort. BMC Pregnancy Childbirth 14:209.

79. Hall AS, Teeny FM, Lewid LG, Hardman WH, Gauglitz, Jr., EJ. 1976. Mercury in fish and shellfish of the Northeast Pacific. I. Pacific halibut, Hippoglossus stenolepsis. Fish Bull 74:783-789.

80. Gerlach R, Teas H. 2014. Environmental contaminants: Alaska fish monitoring program. In Proceedings, 16th Annual Alaska Forum on the Environment, Anchorage, Alaska, USA, February 3-7, 2014.

81. Morrissey MT, Rasmussen R, Okado T. 2004. Mercury content in Pacific troll-caught albacore tuna (Thunnus alalunga). J Aquat Food Prod Technol 13:41-52.

82. Morrissey MT, Geise LA. 2006. Mercury content in Pacific albacore tuna (Thunnus alalunga) during 2006 season. Oregon State University Seafood Laboratory, Astoria, OR, USA.

83. International Pacific Halibut Commission staff, Gustafson K. 2015. Annual Report 2014. International Pacific Halibut Commission, Seattle, WA, USA.

84. HealthLinkBC. 2016. Food safety: Mercury in fish. Nutrition Series $68 \mathrm{~m}$. British Columbia Ministry of Health, Victoria, BC, Canada. 